\title{
Evaluación in vitro del ensilaje de girasol (Helianthus annuus L.) solo y combinado con ensilaje de maíz
}

\section{In vitro evaluation of sunflower (Helianthus annuus L.) silage alone or combined with maize silage}

\author{
Ramón Gonzalo Aragadvay-Yungána, Adolfo Armando Rayas Amorb, Darwin Heredia- \\ Navac, Julieta Gertrudis Estrada-Floresa, Francisco Ernesto Martínez-Castañedaa, \\ Carlos Manuel Arriaga-J ordána
}

\begin{abstract}
RESUMEN
El ensilado de girasol forrajero (Helianthus annuus L.) es promovido para la alimentación del ganado lechero ante escasez de riego y lluvias erráticas. El objetivo fue valorar al ensilado de girasol, solo y en diferentes proporciones con ensilado de maíz mediante degradación in vitro y la cinética de producción de gas. Se realizaron micro-silos, abiertos a los 80 días para el ensilado de maíz (EMz) y 50 días para el ensilado de girasol (EG), evaluándose los siguientes tratamientos (EMz\%: EG\% ); T1) 100:0, T2) 75:25, T3) 50:50, T4) 25:75 y T5) 0:100. En el T2 la fibra detergente neutra y ácida disminuyeron significativamente $(P<0.05)$, resultando en una digestibilidad in vitro de materia seca, materia orgánica, fibra detergente neutra y contenido de energía metabolizable y proteína cruda ( $P>0.05)$ similar a T1. Hubo mayor producción de gas total en T1, pero con una menor tasa de fermentación $(P<0.05)$ al compararlo con T2 cuya tasa de fermentación fue de $0.0530 / \mathrm{h}$, con un tiempo Lag de $3.4 \mathrm{~h}$. El girasol aporta $31.8 \%$ más de PC, $\mathbf{1 1 . 8} \%$ menos de energía metabolizable y $\mathbf{1 1 . 9} \%$ menos de digestibilidad in vitro. Comparado con el T1, el T2 aportó $1.6 \%$ más de proteína, $2 \%$ menos de energía metabolizable y $4.4 \%$ menos de digestibilidad in vitro. Se concluye que el ensilado de girasol podría ser una alternativa para sustituir al ensilado de maíz hasta un $25 \%$, ya que el aporte de proteína y energía es similar al ensilado de maíz solo.
\end{abstract}

PALABRAS CLAVE: Cinética ruminal, Ensilado de girasol, Ensilado de maíz, Gas in vitro, Tasa de fermentación.

\begin{abstract}
Sunflower silage (SS) is being promoted as an efficient forage for feeding dairy cattle in the face of shortages of irrigation and erratic rainfall. The objective was to compare, through the in vitro gas production technique, the kinetics of ruminal fermentation of SS and its mixtures with maize silage (MzS) to know its nutritional characteristics before its inclusion in feeding strategies. Five combinations of SS with MzS were assessed (MzS\%: SS\% ); T1) 100:0, T2) 75:25, T3) 50:50, T4) 25:75 y T5) 0:100. Combining MzS with 25\% SS decreased neutral detergent fiber and acid detergent fiber contents $(P<0.05)$, which resulted in a digestibility of dry mather, organic matter, neutral detergent fiber and metabolizable energy similar to MzS ( $P>0.05)$, and with a CP content not statistically higher than MzS. The MzS had the highest total gas production (GP) but at a lower fermentation rate $(P<0.05)$ when compared to T2 that had a better fermentation rate of $0.0530 \% / h$, with Lag time of 3.4 h. Before ensiling, sunflower supplies $31.8 \%$ more CP, $11.8 \%$ less metabolizable energy and $11.9 \%$ less in vitro digestibility of organic matter than maize plant. Compared to T1, the T2 supplied $1.6 \%$ more crude protein, $2 \%$ less metabolizable energy and $4.4 \%$ less of in vitro digestibility of organic matter. Therefore it is concluded that sunflower silage could be an alternative to substitute up to $25 \%$ of maize silage as the crude protein and metabolizable energy supply are similar to maize silage.
\end{abstract}

KEY WORDS: Ruminal kinetics, Sunflower silage, Maize silage, Gas production, Fermentation rates.

Recibido el 31 de octubre de 2013. Aceptado el 12 de febrero de 2014

a Instituto de Ciencias Agropecuarias y Rurales (ICAR). Universidad Autónoma del Estado de México. Instituto Literario \# 100, Tel. y fax: +52 (722) 296 5552 50000, Toluca, Estado de México, México. cmarriagaj@uaemex.mx. Correspondencia al último autor.

b Departamento de Ciencias de la Alimentación, Universidad Autónoma Metropolitana-Unidad Lerma. Estado de México, México.

c Centro Universitario de los Altos (CUALTOS), Tepatitlán de Morelos, Jalisco. México. 
El girasol (Helianthus annuus L.), es un cultivo que se caracteriza por presentar una alta tolerancia al frío y al déficit de humedad edáfica, además de tener un ciclo de cultivo más corto que el maíz, lo cual hace que se pueda sembrar en zonas propensas a déficit de lluvias como un cultivo alternativo al maíz, y de mejor adaptación a los cambios climáticos inciertos, Iluvias intermitentes y sequias prolongadas, que se han presentado en las últimas décadas, como lo indican los estudios realizados por el Panel Intergubernamental sobre el Cambio Climático(1).

Si bien el estudio del girasol en México no es nuevo, el girasol como ensilado y en comparación al ensilado de maíz, ha demostrado ser uno de los forrajes alternativos para la alimentación de rumiantes.

En estudios previos realizados en Estados Unidos(2), se reportó un rendimiento de leche de $30 \mathrm{~kg} / \mathrm{vaca} /$ día al usar una mezcla de ensilado de maíz-girasol, significativamente mayor con respecto al ensilado de maíz (29 $\mathrm{kg} / \mathrm{vaca} / \mathrm{día}$ ), y los contenidos de ácido oleico y linoléico en leche también fueron mayores al utilizar mezclas de ensilado maíz-girasol.

I gualmente en un estudio en el Noroeste de Estados Unidos con vacas lecheras, no existieron diferencias significativas en producción de leche, contenido de grasa y proteína en leche, y ganancia de peso vivo al comparar ensilado de girasol con ensilado de pasto-alfalfa(3). En un estudio de digestibilidad in vivo de ensilado de maíz y de girasol se reportó que los valores de digestibilidad de la materia seca (MS), fibra detergente neutra (FDN), fibra detergente ácida (FDA) así como el consumo de MS, no presentaron diferencias significativas(4). Los reportes de la composición química del ensilado de girasol indican que es menor a la del ensilado de maíz, excepto por el aporte de proteína cruda y principalmente por el aporte de la grasa con alta densidad calórica por unidad de MS(2).

Con base en estos antecedentes, la utilización de ensilado de girasol en la alimentación de
Sunflower (Helianthus annuus L.), is a crop characterized by a high tolerance to cold and to soil moisture deficit, as well as having a shorter cycle than the corn crop, which favors planting in areas prone to rainfall deficit as an alternative crop to maize, and for better adaptation to uncertain climate changes, intermittent rains and prolonged droughts that have occurred in recent decades, as indicated by studies carried out by the Intergovernmental Panel on Climate Change(1).

The study of the sunflower silage in Mexico is not new, and compared to maize silage, sunflower has proven to be one alternative forage for ruminants feeding.

Previous studies conducted in the United States (2), reported a milk yield of $30 \mathrm{~kg} / \mathrm{cow} / \mathrm{d}$ using a mixture of maize-sunflower silage, value significantly greater than maize silage $(29 \mathrm{~kg} /$ cow $/ d)$; the contents of oleic and linoleic acids in milk were also higher by using mixtures of maize-sunflower silage.

Similarly, in a study in the Northwest of the United States with dairy cows, there were no significant differences in milk production, fat and protein content in milk, and live weight gain in sunflower silage compared with foragealfalfa silage(3). A study of in vivo digestibility of maize and sunflower silage reported similar values of digestibility of dry matter (DM), neutral detergent fiber (NDF), acid detergent fiber (ADF), as well as DM intake(4). Reports of the chemical composition of sunflower silage indicate that it is not as good as the maize silage, except for the contribution of crude protein and mainly by the contribution of fat with high caloric density per unit of $\mathrm{DM}(2)$.

Based on this background, the use of sunflower silage for feeding ruminants can be an alternative to maize silage, particularly in areas where environmental conditions are adverse for the corn crop, so, in this study it was hypothesized that the sunflower silage is an alternative to replace the maize silage in terms 
rumiantes puede ser un alimento alternativo al ensilado de maíz, especialmente en zonas donde las condiciones ambientales son adversas para el cultivo de maíz y de acuerdo con lo mencionado, en este estudio se planteó la hipótesis de que el ensilado de girasol es una alternativa para sustituir al ensilado de maíz en términos de su valor nutricional.

Por lo tanto, el objetivo de este estudio fue evaluar el efecto de la combinación de ensilado de maíz y ensilado de girasol en diferentes proporciones o sin combinar, sobre la composición química, la digestibilidad in vitro y la cinética de producción de gas in vitro.

El presente estudio se llevó a cabo en el laboratorio del Instituto de Ciencias Agropecuarias y Rurales (ICAR), de la Universidad Autónoma del Estado de México. Se utilizó maíz de variedad criolla sembrado el 16 de mayo del 2012 en el municipio de Aculco, ubicado en el noroeste del Estado de México, México, y cosechado a los 157 días. El cultivo de girasol variedad Icamex-1 se sembró el 15 de julio del 2012 en el Centro de Investigación y Transferencia de Tecnología Rancho Arroyo, ubicado en el municipio de Almoloya de Juárez, Estado de México, perteneciente al Instituto de Investigación y Capacitación Agropecuaria, Forestal y Acuícola del Estado de México (ICAMEX) y cosechado a los 127 días de la siembra. Después de la cosecha de ambos cultivos, se procedió a picar las plantas con una longitud promedio de $2.5 \mathrm{~cm}$; posteriormente el forraje picado se colocó en bolsas de plástico con un grosor de 600 micras, sellados con cinta plástica adhesiva para formar micro-silos.

Los micro-silos se abrieron a los 80 días para el ensilado de maíz (EMz) y 50 días para el ensilado de girasol (EG). El pH se determinó al momento de destaparlos tomando una muestra de $20 \mathrm{~g}$ de cada micro-silo, las cuales se colocaron en una licuadora y se agregaron $180 \mathrm{ml}$ de agua destilada a temperatura ambiente, licuándose por $30 \mathrm{seg}$. La mezcla se filtró a través de cuatro capas de tela manta de cielo y el pH se of its nutritional value. Therefore, the objective of this study was to assess the effect of maize silage and sunflower silage combined in different proportions or each one alone, on the chemical composition, in vitro digestibility and kinetics of in vitro gas production.

The present study was conducted in the laboratory of the Institute of Agricultural and Rural Sciences (ICAR), from the Autonomous University of the State of Mexico. The native maize was planted on May 16, 2012 in the municipality of Aculco, located in the Northwest of the State of Mexico, and reaped at $157 \mathrm{~d}$. The sunflower variety Icamex-1 was sown on July 15, 2012 at the center of research and transfer of technology "Rancho Arroyo", located in the municipality of Almoloya de Juárez, State of Mexico, which belongs to the Intitute for Research and Training in Agriculture, Forestry and Aquaculture of the State of Mexico (ICAMEX) and harvested $127 \mathrm{~d}$ after sowing. After the maize and sunflower harvest, the plants were chopped to an average length of $2.5 \mathrm{~cm}$; subsequently the chopped forage was placed in a 600 micron thickness plastic bags; sealed with plastic tape to form micro-silos.

The micro-silos were opened at $80 \mathrm{~d}$ for maize silage (MzS) and $50 \mathrm{~d}$ for sunflower silage (SS). $\mathrm{pH}$ was determined at the time of uncovering them, taking a sample of $20 \mathrm{~g}$ of each microsilo, placed in a blender and $180 \mathrm{ml}$ of distilled water added at room temperature, blending for $30 \mathrm{sec}$. The mixture was filtered through four layers of cheesecloth fabric and $\mathrm{pH}$ was determined in the collected extract using a digital potentiometer.

From the collected samples, a part was taken for the DM determination at 100 to $105^{\circ} \mathrm{C}$ and the remainder of the sample was dried in a forced air oven at $60{ }^{\circ} \mathrm{C}$ for $48 \mathrm{~h}$, and weight was recorded. This method was used because the toluene drag technique was not available for; however in these situations, a correction factor for loss of volatile compounds can be used $(5,6)$ being 1.08 when DM ranges between 
determinó en el extracto colectado utilizando un potenciómetro digital.

De las muestras colectadas se tomó una parte para la determinación de materia seca a temperatura de 100 a $105{ }^{\circ} \mathrm{C}$, el resto de la muestra se desecó en estufa de aire forzado a $60 \stackrel{\circ}{ } \mathrm{C}$ durante $48 \mathrm{~h}$, y se registró el peso. Se utilizó este método debido a que no se disponía de la técnica de arrastre por tolueno; sin embargo ante estas situaciones, se puede utilizar un factor de corrección $(5,6)$ por pérdidas de compuestos volátiles de 1.08 cuando la MS oscila entre 20 a $29 \%$ y de 1.05 para una MS de 30 a $39 \%$, por lo tanto en este estudio el cálculo de la MS contempla dichas correcciones.

Después de haber sido desecadas, las muestras se molieron en un molino Wiley con una malla de $1 \mathrm{~mm}$, y se procedió a realizar las combinaciones del ensilado de maíz con diferentes niveles de ensilado de girasol, obteniéndose cinco tratamientos: T1) EMz $100 \%$; T2) EMz $75 \%$ EG $25 \%$; T3) EMz $50 \%$-EG $50 \%$; T4) EMz $25 \%$-EG $75 \%$; T5) EG $100 \%$.

Todos los análisis se realizaron por duplicado; el contenido de materia seca total (MS) se determinó mediante el secado de $1 \mathrm{~g}$ en una estufa de aire forzado a 100-105 ㄷ durante $24 \mathrm{~h}$, y el contenido de cenizas por incineración en una mufla durante $4 \mathrm{~h}$ a $450 \stackrel{0}{ } \mathrm{C}(7)$. El cálculo de la materia orgánica se realizó mediante la resta de la MS total menos el contenido de cenizas.

Para los análisis posteriores, se utilizaron submuestras que se desecaron a $60{ }^{\circ} \mathrm{C}$ para aminorar el daño por calor. El contenido de nitrógeno se estimó mediante el método micro Kjeldahl(8), la proteína cruda (PC), se calculó como $\mathrm{N} \times 6.25$; el contenido de fibra detergente neutro (FDN) y fibra detergente ácido (FDA) se determinaron con las técnicas recomendadas para estos análisis(9). Para estimar la energía metabolizable, se multiplicó la digestibilidad de la materia orgánica $\times 0.0157^{(9)}$.
20 to $29 \%$ and 1.05 to a DM from 30 to 39 $\%$; therefore in this study, the DM calculations contemplate such corrections.

After drying, samples were ground in a Wiley mill with a $1 \mathrm{~mm}$ mesh, then combinations of the maize silage with different levels of sunflower silage, gave five treatments: T1) MzS $100 \%$; T2) MzS $75 \%$-SS $25 \%$; T3) MzS $50 \%$-SS $50 \%$; T4) MzS $25 \%$-SS $75 \%$; T5) SS $100 \%$.

All analyses were performed in duplicate. Total DM content was determined by drying $1 \mathrm{~g}$ in an air forced oven to $100-105^{\circ} \mathrm{C}$ for $24 \mathrm{~h}$. The ash content was obtained by incineration in a crucible for $4 \mathrm{~h}$ at $450{ }^{\circ} \mathrm{C}(7)$. Calculation of organic matter was done resting the total DM from the ash content.

For subsequent analyses, sub-samples were dehydrated at $60{ }^{\circ} \mathrm{C}$ to minimize damage by heat. The nitrogen content was estimated by the micro Kjeldahl method(8), the crude protein (CP) was calculated as $\mathrm{N} \times 6.25$. The content of neutral detergent fiber (NDF) and acid detergent fiber (ADF) were determined with the recommended techniques for these analyses $(9)$. To estimate the metabolizable energy, digestibility of organic matter was multiplied by $0.0157^{(9)}$.

In vitro gas production (GP) technique was used to evaluate the kinetics of fermentation(10). Glass bottles of $160 \mathrm{ml}$ were used and the GP was measured with a Delta Ohm model D0 9704 pressure transducer. Form each bottle, $0.99 \pm$ $0.01 \mathrm{~g}$ of the sample were incubated, assigning four independent bottles for each sample; one of them was used to measure GP to $120 \mathrm{~h}$ and the rest was used to assess digestibility; each incubation run contemplated four blanks. Each bottle was then added with $90 \mathrm{ml}$ of buffer and $10 \mathrm{ml}$ of ruminal fluid, which was collected from two rumen fistulated adult Holstein cows, $4 \mathrm{yr}$ of age, with $450 \mathrm{~kg}$ average weight; their diet was based on $83 \%$ forage and $17 \%$ commercial concentrate. The ruminal liquid collection was made early in the morning, filtered 
Para evaluar la cinética de fermentación se utilizó la técnica de producción de gas in vitro $(P G)(10)$. En este experimento se usaron botellas de vidrio de $160 \mathrm{ml}$ y la PG se midió con un transductor de presión Delta Ohm modelo DO 9704. Se incubaron $0.99 \pm 0.01 \mathrm{~g}$ de muestra en cada botella, asignando cuatro botellas independientes a cada muestra; una de ellas se utilizó para medir la PG hasta las $120 \mathrm{~h}$ y el resto se empleó para evaluar la digestibilidad; en cada corrida de incubación se contemplaron cuatro blancos. A cada botella se le adicionaron $90 \mathrm{ml}$ de solución amortiguadora y $10 \mathrm{ml}$ de líquido ruminal, el cual se colectó de dos vacas adultas fistuladas, de raza Holstein, de 4 años de edad, con peso promedio de $450 \mathrm{~kg}$ y su alimentación se basó en 83 \% de forraje y $17 \%$ de concentrado comercial. La recolección de líquido ruminal se realizó en las primeras horas de la mañana, se filtró a través de cuatro capas de tela manta de cielo, y se colocó en un termo calentado previamente a $39{ }^{\circ} \mathrm{C}$, que se transportó rápidamente hacia el laboratorio para la inoculación.

Las mediciones de producción de gas se tomaron con el transductor de presión a las horas $1,2,3,4,5,6,7,8,12,16,20,28$, $36,44,52,60,72,84,96$, y 120 posterior a la incubación.

La digestibilidad in vitro se evaluó transcurrido el periodo de incubación, que fue a las 48 h, empleando una botella para evaluar la digestibilidad de la MS, la MO y de la FDN. El sustrato residual se removió con agua destilada y se filtró en crisoles Gooch (\#1); la MS residual filtrada se colocó en una mufla a $105{ }^{\circ} \mathrm{C}$ por una hora; este peso seco se registró y la digestibilidad in vitro de la materia seca (DIVMS) se determinó por diferencia de peso entre la MS inicial y la MS residual. Posteriormente la MS residual se colocó en una mufla a $450{ }^{\circ} \mathrm{C}$ durante $4.5 \mathrm{~h}$, para determinar el contenido de cenizas y posteriormente calcular la materia orgánica (MO) residual; la digestibilidad in vitro de la materia orgánica (DIVMO) se calculó por diferencia de peso entre la MO inicial menos la through four layers of cheesecloth fabric, and placed in a thermos previously heated at 39 ${ }^{\circ} \mathrm{C}$, which was quickly transported to the laboratory for inoculation.

Gas production measurements were taken with pressure transducer at hours $1,2,3,4,5,6,7$, $8,12,16,20,28,36,44,52,60,72,84,96$ and 120 after incubation.

In vitro digestibility was evaluated at the end of the incubation period, which was $48 \mathrm{~h}$, using one bottle to evaluate the digestibility of DM, $O M$ and NDF. The residual substrate was removed with distilled water and filtered in Gooch (\#1) crucibles; the residual DM was placed in a flask at $105{ }^{\circ} \mathrm{C}$ for one hour, this dry weight was recorded and in vitro digestibility of dry matter (IVDDM) was determined by difference in weight between the initial and residual DM. Subsequently, the residual DM was placed in a flask to $450{ }^{\circ} \mathrm{C}$ for $4.5 \mathrm{~h}$ to determine the ash content and then calculate the residual $\mathrm{OM}$; in vitro digestibility of organic matter (IVDOM) was calculated by weight difference between the initial and the residual OM. For neutral detergent fiber in vitro digestibility calculation (NDFIVD) bottle fermentation waste, was removed with $50 \mathrm{ml}$ of NDF, were subsequently placed in an autoclave at $105^{\circ} \mathrm{C}$ for one hour, filtered in a Gooch (\#1) crucible and the residue was placed in a flask at $105^{\circ} \mathrm{C}$ for one hour to dry, then weight was recorded, and afterwards incinerated in a flask to $450{ }^{\circ} \mathrm{C}$ for $4 \mathrm{~h}$. The IVDDM calculation was performed by weight difference between the initial and residual NDF content(11).

In vitro fermentation parameters were estimated by adjusting the volume of accumulated gas from each bottle, to the developed mathematical model for these studies(12), using the Marquart logarithm implemented in Grafit v3(13), as shown in the following equation:

$\mathrm{GP}=\mathrm{B}(1-\exp -\mathrm{c}(\mathrm{t}-\mathrm{lag}))$

Where: $\mathrm{GP}=$ total gas production $(\mathrm{ml}$ gas/100 mg DM); $B=$ asymptote of the neutral detergent 
MO residual. Para el cálculo de la digestibilidad in vitro de la fibra detergente neutro (DIVFDN) los residuos de la fermentación de las botellas, se removieron con $50 \mathrm{ml}$ de solución FDN; posteriormente se colocaron en una autoclave a $105{ }^{\circ} \mathrm{C}$ por una hora, se filtraron en crisoles Gooch (\#1) y el residuo se colocó en una mufla a una temperatura de $105{ }^{\circ} \mathrm{C}$ por una hora, se registró el peso seco del residuo y posteriormente, se incineró en una mufla a 450 ${ }^{\circ} \mathrm{C}$ por $4 \mathrm{~h}$. El cálculo de la DIVMS se realizó por diferencia de peso entre el contenido de FDN inicial en la muestra menos el contenido de FDN residual(11).

Los parámetros de fermentación in vitro se estimaron mediante el ajuste del volumen de gas acumulado de cada botella, al modelo matemático desarrollado para estos estudios(12), usando el logaritmo Marquart implementado en Grafit v3(13), como se muestra en la siguiente ecuación:

$P G=B\left(1-\exp { }^{-c}(t-l a g)\right)$

Donde: $\mathrm{PG}=$ producción total de gas ( $\mathrm{ml}$ gas / 100 mg MS); $B=$ producción asíntota de gas de la fermentación de la fibra detergente neutra; $c=$ tasa de degradación de producción de gas (por hora); lag= tiempo transcurrido antes de que empiece la fermentación de los carbohidratos estructurales.

Para el análisis estadístico de los datos se empleó un diseño completamente al azar; el modelo general lineal fue $Y_{i j}=\mu+T_{i}+e_{i j}$; en donde $Y_{i j}$ es la variable de respuesta perteneciente al j-ésimo elemento y al i-ésimo tratamiento, $\mu$ es la media general, $T$ es efecto debido al i-ésimo tratamiento y $\mathrm{e}_{\mathrm{ij}}$ es el error experimental asociado al j-ésimo elemento del i-ésimo tratamiento. Para evaluar las posibles tendencias lineales (L), cuadráticas (Q) o cúbicas (C) en cada una de las variables y debido a los tratamientos, se realizó un análisis de polinomios ortogonales; el modelo general fue:

t $\mathrm{C}_{\mathrm{j}}=\Sigma \mathrm{C}_{\mathrm{ij}} \mathrm{T}_{\mathrm{i}} \mathrm{i}=1$

En donde $\mathrm{C}$ es el contraste, $\mathrm{C}_{\mathrm{ij}}$ es el coeficiente fiber fermentation gas production; $c=$ degradation rate of gas production (per hour); lag= time elapsed before the start of the structural carbohydrates fermentation.

A completely randomized design was used for the statistical analysis of the data. The general linear model was Yij $=\mu+\mathrm{Ti}+$ eij; where Yij is the j-th element response variable to the $\mathrm{i}$-th treatment, $\mu$ is the general mean, $T$ is effective due to the $\mathrm{i}$-th treatment and eij is the experimental error associated with the $j$-th element of the $i$-th treatment. Because of the treatments and in order to evaluate the possible linear (L), quadratic (Q) or cubic (C) trends for each of the variables, an analysis of orthogonal polynomials was performed. The general model was:

$\mathrm{t} \mathrm{C}_{\mathrm{j}}=\Sigma \mathrm{C}_{\mathrm{ij}} \mathrm{T}_{\mathrm{i}} \mathrm{i}=1$

Where $\mathrm{C}$ is the contrast, $\mathrm{Cij}$ is the coefficient of the treatment in the contrast $\mathrm{j}$, and $\mathrm{Ti}$ is the total of the i treatment. The variables of chemical analysis, in vitro digestibility, in vitro fermentation parameters and the analysis of orthogonal polynomials were performed using the GLM procedure implemented in the Minitab Statistical software(14). The analysis of variance (ANOVA) was performed for each of the variables and to observe significant differences $(P<0.05)$ the

Cuadro 1. Composición química de la planta de maíz y girasol antes de ensilar ( $\left.\mathrm{g} \mathrm{kg}^{-1} \mathrm{DM}\right)$

Table 1. Chemical composition of the maize and sunflower plants before ensiling $\left(\mathrm{g} \mathrm{kg}^{-1} \mathrm{DM}\right)$

\begin{tabular}{lccc}
\hline & Maize plant & Sunflower plant & SEM \\
\hline Ashes & $60 \mathrm{a}$ & $98 \mathrm{~b}$ & 0.02 \\
OM & $940 \mathrm{~b}$ & $902 \mathrm{a}$ & 0.02 \\
CP & $66 \mathrm{a}$ & $87 \mathrm{~b}$ & 0.14 \\
NDF & $554 \mathrm{~b}$ & $442 \mathrm{a}$ & 0.67 \\
ADF & $262 \mathrm{a}$ & $267 \mathrm{a}$ & 0.82 \\
\hline
\end{tabular}

$\mathrm{SEM}=$ standard error of the mean; $\mathrm{DM}=$ dry matter; $\mathrm{OM}=$ organic matter; $\mathrm{CP}=$ crude protein; $\mathrm{NDF}=$ neutral detergent fiber; $A D F=$ acid detergent fiber.

ab Values with distinct superscript, differ $(P<0.05)$. 
del tratamiento en el contraste $\mathrm{j}$ y $\mathrm{T}_{\mathrm{j}}$ es el total del tratamiento i. Las variables del análisis bromatológico, digestibilidad in vitro, los parámetros de fermentación in vitro y el análisis de polinomios ortogonales se realizaron empleando el procedimiento GLM implementado en el software estadístico Minitab(14). El análisis de varianza (ANOVA) se realizó para cada una de las variables y al observarse diferencias significativas $(P<0.05)$ se realizó la prueba de comparación de medias de Tukey. En el análisis de polinomios ortogonales, las tendencias $\mathrm{L}, \mathrm{Q}$ y $C$ se consideraron significativas a un nivel de $P<0.05$.

La composición química de la planta de maíz y el girasol antes de ensilar se muestran en el Cuadro 1. En general los valores de cenizas, MO, PC, FDN, mostraron diferencias $(P<0.05)$ entre los forrajes evaluados; excepto para FDA $(P>0.05)$.

En el Cuadro 2 se muestra el pH y la composición química para los diferentes tratamientos; tanto el pH como el contenido de MS en T1 y T5 mostraron diferencias $(P<0.05)$ y una tendencia lineal creciente $(P<0.001)$ con respecto al incremento en la proporción de EG.
Tukey multiple comparison test was performed. In the analysis of orthogonal polynomials, L, Q and $\mathrm{C}$ trends were considered significant at a level of $P<0.05$.

The chemical composition of the maize and the sunflower plants before ensiling are shown in Table 1. In general the values for ashes, OM, $C P, N D F$, showed differences $(P<0.05)$ between the evaluated fodder; except for ADF $(P>0.05)$.

Table 2 shows the $\mathrm{pH}$ and chemical composition for the different treatments; both $\mathrm{pH}$ and DM content in T1 and T5 showed differences $(P<0.05)$ and an increasing linear trend $(P<0.001)$ with regard to the increase in the SS proportion. The $\mathrm{pH}$ values of $\mathrm{T} 1$ were close to those reported by other authors(15), who found $\mathrm{pH}$ values of 3.9 in MzS. These results of $\mathrm{pH}$ in MzS together with DM contents are acceptable characteristics that demonstrate a good preservation process(16). On the other hand, $\mathrm{pH}$ of the $\mathrm{T} 5$ was close to that found in a work in $\mathrm{Brazil}^{(17)}$, which reported values between 4.5 and 4.1 for a combination of MzS-SS in a 60:40 ratio respectively $(2)$. These $\mathrm{pH}$ values indicate a high buffer capacity, because this type of forages have low dry matter contents and water soluble

Cuadro 2. Composición química de ensilados de maíz y girasol, solos o combinados ( $\left.\mathrm{g} \mathrm{kg}^{-1}\right)$

Table 2. Chemical composition of maize and sunflower silages, alone or combined $\left(\mathrm{g} \mathrm{kg}^{-1}\right)$

\begin{tabular}{|c|c|c|c|c|c|c|c|c|}
\hline & \multicolumn{5}{|c|}{ Treatments } & \multicolumn{2}{|c|}{ Tendency } & \multirow[b]{2}{*}{ SEM } \\
\hline & $\mathrm{T} 1$ & $\mathrm{~T} 2$ & T3 & $\mathrm{T} 4$ & 15 & $L$ & $\mathrm{C}$ & \\
\hline $\mathrm{pH}$ & $3.8 \mathrm{a}$ & $3.9 \mathrm{a}$ & $3.6^{a}$ & $3.8^{a}$ & $4.7 \mathrm{~b}$ & $* * *$ & & 0.03 \\
\hline DM & $318.0 \mathrm{a}$ & $335.0 \mathrm{a}$ & $322.0 \mathrm{a}$ & $296.0^{a}$ & $245.0 \mathrm{~b}$ & $* * *$ & & 1.7 \\
\hline Ashes & $61.0 \mathrm{a}$ & $68.0 \mathrm{~b}$ & $77.0 \mathrm{c}$ & $78.0^{c}$ & $105.0 \mathrm{~d}$ & $\star \star \star *$ & & 0.5 \\
\hline OM & $939.0 \mathrm{~d}$ & $932.0^{\mathrm{C}}$ & $923.0 \mathrm{~b}$ & $922.0 \mathrm{~b}$ & $895.0 \mathrm{a}$ & $* * *$ & & 0.5 \\
\hline $\mathrm{CP}$ & $63.0 \mathrm{a}$ & $64.0 \mathrm{a}$ & $59.0 \mathrm{a}$ & $62.0 \mathrm{a}$ & $81.0 \mathrm{~b}$ & & $* * *$ & 0.7 \\
\hline NDF & $485.0^{b}$ & $456.0 \mathrm{a}$ & $498.0 \mathrm{~b}$ & $488.0 \mathrm{~b}$ & $462.0 \mathrm{a}$ & & * & 3.5 \\
\hline ADF & $244.0 \mathrm{a}$ & $235.0 \mathrm{a}$ & $283.0 \mathrm{~b}$ & $279.0 \mathrm{~b}$ & $283.0 \mathrm{~b}$ & & $* * *$ & 2.5 \\
\hline
\end{tabular}

$\mathrm{T} 1=100 \%$ maize silage, $\mathrm{T} 2=75 \%$ maize silage $25 \%$ sunflower silage, $\mathrm{T} 3=50 \%$ maize silage $50 \%$ sunflower silage, $\mathrm{T} 4=25 \%$ maize silage $75 \%$ sunflower silage, $\mathrm{T} 5=100 \%$ sunflower silage.

$\mathrm{L}=$ lineal, $\mathrm{C}=$ cubic; $\mathrm{SEM}=$ standard error of the mean.

$\mathrm{DM}=$ dry matter; $\mathrm{OM}=$ organic matter; $\mathrm{CP}=$ crude protein; $\mathrm{NDF}=$ neutral detergent fiber; $\mathrm{ADF}=$ acid detergent fiber.

abcd Values with distinct superscript, differ $(P<0.05)$. 
Los valores de $\mathrm{pH}$ del T1 fueron cercanos a lo reportado por otros autores(15), quienes encontraron valores de $\mathrm{pH}$ de 3.9 para EMz. Estos resultados de $\mathrm{pH}$ en EMz junto al contenido de MS son características aceptables que evidencian un buen proceso de conservación(16). Por otro lado, el pH del T5 fue cercano al encontrado por trabajos en Brasil(17), en los que reportan valores entre 4.5 y de 4.1 para una combinación de EMz-EG a una proporción de 60:40 respectivamente(2); estos valores de $\mathrm{pH}$ indican una alta capacidad buffer, debido a que este tipo de forrajes tienen bajos contenidos de materia seca y de carbohidratos hidrosolubles disponibles para la fermentación(18) y que posteriormente son convertidos a ácido láctico.

En el análisis bromatológico de los ensilados, los contenidos de cenizas y MO de los tratamientos T3 y T4 fueron similares $(P>0.05)$, a diferencia de T1, T2 y T5. Los contenidos de PC fueron similares en todos los tratamientos, excepto en T5 (81 $\left.\mathrm{g} \mathrm{kg}^{-1} \mathrm{MS}, \quad P<0.05\right)$; el contenido de $\mathrm{PC}$ que se reporta en este estudio resultó inferior a lo reportado en la literatura(2), que es de $100 \mathrm{~g} \mathrm{~kg}^{-1}$ MS para el caso de la combinación maíz-girasol y hasta 115 g en EG sin combinar.

La composición química de los ensilados tienen relación con las tendencias que se dan entre forrajes al evaluarlos solos o combinados(19). En el Cuadro 2, se observa una tendencia lineal decreciente $(P<0.001)$ en el contenido de MO con respecto al incremento en la proporción de EG: a mayor proporción en la combinación menor es el contenido de MO.

Para las variables de PC, FDN y FDA la tendencia fue cúbica $(P<0.01)$, lo que sugiere que a mayor proporción de EG mayor es el contenido de estas variables, pero este incremento no es constante y tiene un punto asintótico.

El EG presentó mayor contenido de PC que el EMz $(P<0.05)$, sin embargo no se observaron incrementos $(P>0.05)$ al combinarlo con el EMz; carbohydrates available for fermentation(18) that are subsequently converted to lactic acid.

Chemical silage analysis, ash content and OM of T3 and T4 were similar ( $P>0.05)$, unlike T1, $\mathrm{T} 2$ and T5. Contents of $\mathrm{CP}$ were similar in all treatments, except for T5 (81 g kg-1 MzS, $P>0.05)$. The CP content in this study was lower than that reported in the literature ${ }^{(2)}$, which is $100 \mathrm{~g} \mathrm{~kg}^{-1} \mathrm{DM}$ for the case of the maizesunflower combination and up to $115 \mathrm{~g}$ in SS alone.

The silage chemical composition relates to trends that occur between fodders by evaluating them alone or in combination(19). In Table 2, there is a decreasing linear trend $(P<0.001)$ in OM content with regard to the increase in the proportion of SS: the higher the proportion in combination, the lower OM content.

For $\mathrm{CP}, \mathrm{NDF}$ and ADF variables trend were cubic $(P<0.01)$, which suggests that to a greater SS proportion, higher the contents of these variables, but this increase is not constant and has an asymptotic point.

SS presented higher content of $\mathrm{CP}$ than the MzS $(P<0.05)$, however no increments were observed $(P>0.05)$ when combined with the $\mathrm{MzS}$; this was contrary to the results reported on crops associated with maize forage(20), indicating increases in the $\mathrm{CP}$ content in associated silage versus maize silage maizesunflower; only the T2 showed a slight increase (1 $\mathrm{g} \mathrm{kg}^{-1} \mathrm{DM}$ ) with respect to T1 which can be explained due to the low content of CP presented in the SS (T5) with respect to other studies(2).

As a result of the process of the plant corn silage, it was observed that NDF content decreased in MzS form 554 to $485 \mathrm{~g} \mathrm{~kg}^{-1} \mathrm{DM}$, probably due to the high use of hemicellulose, as has been suggested in other studies(21), favoring perhaps the increase in the use of DM in in vivo studies(22).

The values of $\left(\mathrm{g} \mathrm{kg}^{-1} \mathrm{DM}\right)$ and in vitro digestibility of maize and sunflower, before 
esto fue contrario a los resultados reportados en trabajos sobre cultivos asociados con maíz forrajero(20), que indican incrementos en el contenido de PC en ensilados asociados maízgirasol versus ensilado de maíz; solamente el T2 mostró un ligero incremento ( $1 \mathrm{~g} \mathrm{~kg}^{-1} \mathrm{MS}$ ) con respecto al $\mathrm{T} 1$, lo que puede explicarse debido al bajo contenido de PC que presentó el EG (T5) con respecto a otros estudios(2).

Como resultado del proceso del ensilaje de la planta de maíz, se observó que el contenido de FDN disminuyó en EMz de 554 a $485 \mathrm{~g} \mathrm{~kg}^{-1}$ MS, probablemente por la alta utilización de la hemicelulosa como se ha indicado en otros estudios(21), lo que favorece quizá el incremento en el consumo de MS en estudios in vivo(22).

Los valores de digestibilidad in vitro $\left(\mathrm{g} \mathrm{kg}^{-1}\right.$ MS) del maíz y girasol, antes de ser ensilados, presentaron diferencias significativas $(P<0.05)$, para todas las variables de DIVMS, DIVMO, y DIVFDN. Además se presentaron diferencias $(P<0.05)$ en los valores de energía metabolizable (MJ $\mathrm{kg}^{-1} \mathrm{MS}$ ) entre el maíz y girasol (Cuadro 3).

El Cuadro 4, presenta valores de digestibilidad in vitro y energía metabolizable de los tratamientos. En la DIVMS y la DIVMO de T1 y T2 no se observaron diferencias a excepción de DIVFDN $(P<0.05)$, y estos a su vez fueron diferentes $(P<0.05)$ de T3, T4, y T5. La DIVMS, DIVMO y de la DIVFDN mostraron una tendencia lineal decreciente, ya que a medida que se incrementó la proporción de EG su digestibilidad in vitro disminuyó, lo cual tuvo un efecto negativo en el contenido de EM. En estudios previos(19) que relacionan contenidos de EM con valores de digestibilidad de carbohidratos estructurales, al estudiar EMz combinado con girasol, col rizada y frijol, indican que los bajos contenidos de EM de los EMz-EG se atribuyen a la disminución en la digestibilidad. Esta disminución en los carbohidratos estructurales podría explicarse con el hecho de que el ensilado de girasol contiene grasas y aceites que disminuyen el conteo de microorganismos
Cuadro 3. Digestibilidad in vitro y energía metabolizable estimada (ME) de plantas de maíz y girasol antes de ensilar

Table 3. In vitro digestibility and metabolizable energy (ME) estimated of maize and sunflower plant before ensiling

\begin{tabular}{lccc}
\hline & Maize plant & Sunflower plant & SEM \\
\hline DMIVD, $\mathrm{g} \mathrm{kg}^{-1}$ & $688 \mathrm{~b}$ & $632 \mathrm{a}$ & 0.39 \\
OMIVD, g kg-1 DM & $646 \mathrm{~b}$ & $569 \mathrm{a}$ & 0.35 \\
NDFIVD, g kg-1 DM & $635 \mathrm{~b}$ & $493 \mathrm{a}$ & 0.91 \\
ME, MJ kg-1 DM & $10.1 \mathrm{a}$ & $8.9 \mathrm{~b}$ & 0.05
\end{tabular}

$\mathrm{SEM}=$ standard error of the mean; DMIVD= dry matter in vitro digestibility; OMIVD= organic matter in vitro digestibility; NDFIVD= neutral detergent fiber in vitro digestibility; $M E=$ metabolizable energy; $\mathrm{DM}=$ dry matter.

ab Values with distinct superscript, differ $(P<0.05)$.

ensiling, presented significant differences $(P<0.05)$, for all variables of OMIVD, DMIVD and NDFIVD. In addition there were differences $(P<0.05)$ on the values of metabolizable energy (ME) (MJ kg-1 DM) between maize and sunflower (Table 3).

Table 4 presents values of in vitro digestibility and metabolizable energy of the treatments. OMIVD and DMIVD of T1 and T2 were similar with the exception of NDFIVD $(P<0.05)$, and these in turn were different $(P<0.05)$ of $T 3, T 4$, and T5. The DMIVD, OMIVD and the NDFIVD showed a decreasing linear trend, as the proportion of SS increased its in vitro digestibility declined, which had a negative effect on the DM content. In previous studies(19) relating contents of ME with structural carbohydrate digestibility values, studying MzS combined with sunflower, kale and beans, indicate that the low level of the ME content with MzS-SS are attributed to decreased digestibility. This decrease in structural carbohydrates could be explained by the fact that sunflower silage contains fats and oils that decrease ruminal microorganisms count(6), which could suggest that there are fewer microorganisms for the substrate degradation. In this regard, the contribution of ME in the T1 and T2 was similar $(P>0.05)$. 
Cuadro 4. Digestibilidad in vitro y energía metabolizable estimada (ME) de los ensilados de maíz y girasol solos 0 combinados

Table 4. In vitro digestibility and estimated metabolizable energy (ME) of the maize and sunflower silages alone or in combination

\begin{tabular}{|c|c|c|c|c|c|c|c|}
\hline & \multicolumn{5}{|c|}{ Treatments } & \multirow{2}{*}{$\begin{array}{c}\text { Tendency } \\
\mathrm{L} \\
\end{array}$} & \multirow[b]{2}{*}{ SEM } \\
\hline & $\mathrm{T} 1$ & $\mathrm{~T} 2$ & T3 & T4 & T5 & & \\
\hline DMIVD, $\mathrm{g} \mathrm{kg}^{-1} \mathrm{DM}$ & $698.0 \mathrm{~b}$ & $673.0 \mathrm{~b}$ & $609.0 \mathrm{a}$ & $595.0^{a}$ & $591.0 \mathrm{a}$ & $* * *$ & 0.36 \\
\hline OMIVD, $\mathrm{g} \mathrm{kg}^{-1} \mathrm{DM}$ & $656.0 \mathrm{~b}$ & $627.0 \mathrm{~b}$ & $563.0 \mathrm{a}$ & $548.0 \mathrm{a}$ & 529.0 a & *** & 0.34 \\
\hline NDFIVD, $\mathrm{g} \mathrm{kg}^{-1} \mathrm{DM}$ & $520.0^{c}$ & $552.0^{c}$ & $473.0 \mathrm{~b}$ & $441.0^{a}$ & $428.0 \mathrm{a}$ & * & 0.32 \\
\hline ME, MJ kg-1 DM & $10.0 \mathrm{~b}$ & $9.8 \mathrm{~b}$ & $8.8 \mathrm{a}$ & 8.6 a & 8.3.0 a & *** & 0.05 \\
\hline
\end{tabular}

$\mathrm{T} 1=100 \%$ maize silage, $\mathrm{T} 2=75 \%$ maize silage $25 \%$ sunflower silage, $\mathrm{T} 3=50 \%$ maize silage $50 \%$ sunflower silage, T4= $25 \%$ maize silage $75 \%$ sunflower silage, $T 5=100 \%$ sunflower silage.

$\mathrm{L}=$ lineal; $\mathrm{SEM}=$ standard error of the mean.

DMIVD= dry matter in vitro digestibility; OMIVD= organic matter in vitro digestibility; NDFIVD= neutral detergent fiber in vitro digestibility; ME= metabolizable energy; $\mathrm{DM}=$ dry matter.

abc Values with distinct superscript, differ $(P<0.05)$.

ruminales(6), lo cual podría sugerir que hay menor cantidad de microorganismos para efectuar la degradación del sustrato; en este sentido el aporte de EM del T1 y T2 fue similar $(P>0.05)$.

Los parámetros del ajuste de la producción acumulada de gas (PG) in vitro de los tratamientos se muestran en el Cuadro 5. No se observaron diferencias $(P>0.05)$ en la fracción "B" entre T3 y T4, sin embargo estos fueron diferentes a los demás tratamientos, de los cuales el T1 presentó la PG más alta (Figura 1). Las tasas de fermentación (c) de la fracción " $B$ " más altas se observaron en T4 y T5, las cuales fueron diferentes $(P<0.05)$ a los demás tratamientos. El lag en el modelo presentado(12), indica el tiempo en que los microorganismos comienzan la degradación de la fracción "B" (carbohidratos estructurales); en este estudio el T5 presentó mayor tiempo lag $(h)$, que difiere $(P<0.05)$ del resto de los tratamientos, y T2 mostró el menor tiempo lag, lo cual sugiere que el contenido de carbohidratos de rápida degradación (azúcares, almidón y pectinas) en T5 es mayor que en T2. En este trabajo, el tiempo lag mostró una
The adjusted parameters of the accumulated in vitro gas production treatments are shown in Table 5. There were no differences $(P>0.05)$ in the fraction " $\mathrm{B}$ " between $\mathrm{T} 3$ and $\mathrm{T} 4$, however these were different from the other treatments, of which T1 presented the highest GP value (Figure 1). Rates of fermentation (c) from fraction " $\mathrm{B}$ " were higher in $\mathrm{T} 4$ and $\mathrm{T} 5$, which were different $(P<0.05)$ to all other treatments. The lag in the presented model(12), indicates the time when microorganisms start degradation of fraction " $\mathrm{B}$ " (structural carbohydrates). In this study the T5 presented greater lag time (h), which is different $(P<0.05)$ from the rest of the treatments and T2 showed the least lag time, which suggests that the carbohydrates content (sugars, starch and pectin) degrade rapidly in T5 compared to T2. In this work, lag time showed a quadratic tendency with regard to the SS proportion.

Table 5 also shows that the fraction "B" and GP accumulated at $24 \mathrm{~h}$ showed a decreasing linear trend $(P<0.001)$ with regard to the increase in the proportion of SS; by the contrary " $\mathrm{C}$ " showed an increasing linear trend $(P<0.001)$; " $C$ " is related to the substrate fermentation that in turn is related to the type of structural 
Cuadro 5. Ajuste al modelo matemático de la producción acumulada de gas (GP) in vitro de los ensilados de maíz y girasol solos o combinados

Table 5. Adjustment to the mathematical model of the accumulated in vitro gas production (GP) of the maize and sunflower silages alone or in combination

\begin{tabular}{|c|c|c|c|c|c|c|c|c|c|}
\hline & \multicolumn{5}{|c|}{ Treatments } & \multicolumn{3}{|c|}{ Tendency } & \multirow[b]{2}{*}{ SEM } \\
\hline & T1 & T2 & T3 & $\mathrm{T} 4$ & T5 & $\mathrm{L}$ & $Q$ & $\mathrm{C}$ & \\
\hline $\mathrm{B}, \mathrm{ml}$ gas $\mathrm{g}^{-1} \mathrm{DM}$ & $240 d$ & $233^{c}$ & $221 \mathrm{~b}$ & $217 b$ & $180^{a}$ & *** & & & 0.71 \\
\hline$c, \% \mathrm{~h}^{-1}$ & $4.6 \mathrm{a}$ & $5.3 \mathrm{~b}$ & $5.4 \mathrm{~b}$ & $6.1 \mathrm{c}$ & $6.4^{c}$ & $* * *$ & & & 2.73 \\
\hline Lag, $\mathrm{h}^{-1}$ & $3.8^{c}$ & $3.4^{a}$ & $3.5 \mathrm{~b}$ & $3.5 \mathrm{~b}$ & $4.0 \mathrm{~d}$ & & *** & & 0.01 \\
\hline GP to $24 \mathrm{~h}$ & $144 \mathrm{~b}$ & $154 c$ & $145 \mathrm{~b}$ & $152 c$ & $129 a$ & *** & ** & 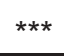 & 0.49 \\
\hline
\end{tabular}

$\mathrm{T} 1=100 \%$ maize silage, $\mathrm{T} 2=75 \%$ maize silage $25 \%$ sunflower silage, $\mathrm{T} 3=50 \%$ maize silage $50 \%$ sunflower silage, $\mathrm{T} 4=25 \%$ maize silage $75 \%$ sunflower silage, $T 5=100 \%$ sunflower silage.

$\mathrm{L}=$ lineal, $\mathrm{Q}=$ quadratic, $\mathrm{C}=$ cubic, $\mathrm{SEM}=$ standard error of the mean.

$\mathrm{B}=$ asymptotic gas production $\left(\mathrm{ml}\right.$ gas $\left./ \mathrm{g}^{-1} \mathrm{DM}\right)$ from the fermentation of neutral detergent fiber; $\mathrm{c}=$ fractional rate of gas production $\left(\mathrm{h}^{-1}\right)$ in a time $\mathrm{t}$, lag= time in hours before the NDF fermentation; GP= gas production.

abcd Values with distinct superscript, differ $(P<0.05)$.

tendencia cuadrática con respecto a la proporción de EG.

En el Cuadro 5 también se muestra que la fracción "B" y la PG acumulada a las $24 \mathrm{~h}$ mostraron una tendencia lineal decreciente $(P<0.001)$ con respecto al incremento en la proporción de EG; por el contrario " $\mathrm{C}$ " mostró una tendencia lineal creciente $(P<0.001)$; " $\mathrm{C}$ " está relacionada con la fermentación del sustrato y que a su vez se relaciona con el tipo de carbohidratos estructurales en el sustrato(23), lo cual sugiere mayor celulosa para los microorganismos ruminales.

En la Figura 1 se muestran los perfiles de gas acumulado en los diferentes tratamientos; se observa que durante las primeras $8 \mathrm{~h}$ post incubación la PG acumulada es similar entre los tratamientos $(P>0.05)$, sin embargo a partir de las $24 \mathrm{~h}$ se observó que el T5 produjo menor cantidad de gas que el resto de los tratamientos; esto claramente refleja que la velocidad de degradación es alta pero con poco sustrato en la fracción "B".

Tomando como base a la planta del maíz antes de ensilar, la planta de girasol aporta 31.8 \% más proteína cruda, 11.8 \% menos carbohydrate on the substrate(23), which suggests more cellulose for ruminal microorganisms.

Figure 1 shows the profiles of gas accumulated in the different treatments. During the first 8 $h$ post incubation, accumulated GP is similar among treatments $(P>0.05)$; however, from $24 \mathrm{~h}$

Figura 1. Cinética de fermentación de ensilados de maíz y girasol, a las 120 h de incubación

Figure 1. Fermentation kinetics of maize and sunflower silages, at $120 \mathrm{~h}$ of incubation

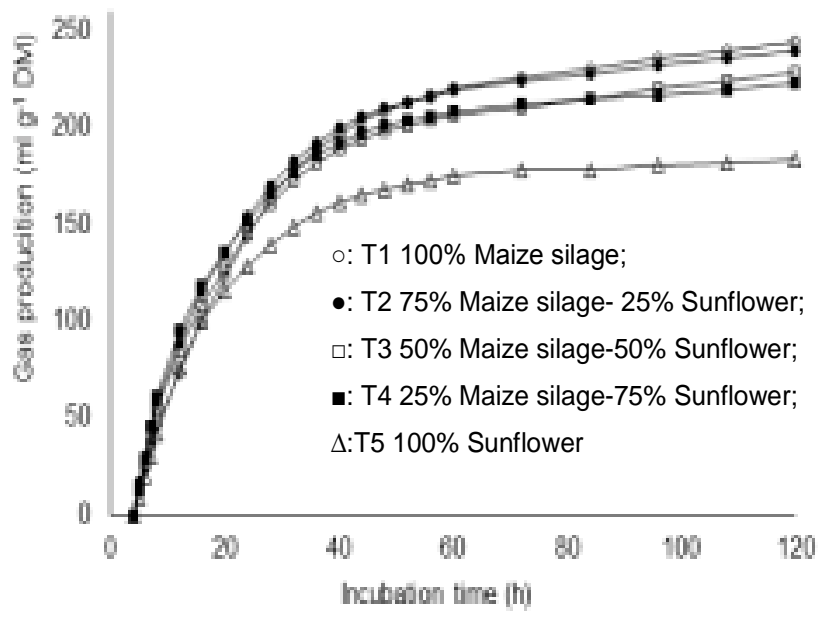


de energía metabolizable y $11.9 \%$ menos de digestibilidad in vitro. Comparado con el ensilaje de maíz, el ensilado de girasol aportó $1.6 \%$ más de proteína, $2 \%$ menos de energía y 4.4 $\%$ menos de digestibilidad in vitro de la materia orgánica. Por lo tanto, el ensilado de girasol podría ser una alternativa para sustituir al ensilado de maíz hasta en un $25 \%$, ya que el aporte de proteína y energía es similar al ensilado de maíz sin combinar.

\section{AGRADECIMIENTOS}

Los autores expresan su agradecimiento a la T.L. Laura Edith Martínez Contreras y la T.L. María de Lourdes Maya Salazar por su invaluable apoyo. Al M. en F. Fermín Bravo Quirino por su apoyo con el cultivo de girasol. Este trabajo se realizó dentro del proyecto "Evaluación de la sustentabilidad de sistemas de producción de leche en pequeña escala" financiado por CONACYT con clave 129449 CB-2009 y gracias al financiamiento de la Agencia Española de Cooperación Internacional para el Desarrollo de España a través del proyecto clave AECID 11-CAP2-1526. Se agradece igualmente a la Secretaría Nacional de Educación Superior, Ciencia, Tecnología e Innovación (SENESCYT) del Gobierno de Ecuador por la beca para los estudios de posgrado de Ramón Gonzalo Aragadvay Yungán.

\section{LITERATURA CITADA}

1. PCC. Intergovernmental Panel on Climate Change. Working Group I. Newsletter No 8. WMO, UNEP. 2001.

2. Valdez FR, Harrison JH, Fransen SC. Effect of feeding cornsunflower silage on milk production, milk composition, and rumen fermentation of lactating dairy cows. J Dairy Sci $1988 ; 71: 2462-2469$.

3. Thomas VM, Murray GA, Thacker DL, Sneddon DN. Sunflower silage in rations for lactating Holstein cows. J Dairy Sci 1982;65:267-270.

4. Valdez FR, Harrison JH, Deetz DA, Fransen SC. In vivo digestibility of corn and sunflower intercropped as a silage crop. J Dairy Sci 1988;71:1860-1867. it was observed that the T5 produced less gas than the rest of the treatments; This clearly reflects that the rate of degradation is high but with low substrate in fraction " $\mathrm{B}$ ".

On the basis of the maize plant before ensiling, the sunflower plant provide $31.8 \%$ more crude protein, $11.8 \%$ less metabolizable energy and $11.9 \%$ less in vitro digestibility. Compared to maize silage, the sunflower silage provide $1.6 \%$ more protein, $2 \%$ less energy and $4.4 \%$ less in vitro digestibility of organic matter. Therefore, the sunflower silage could be an alternative to replace $25 \%$ of maize silage, as protein and energy contribution are similar to maize silage alone.

\section{ACKNOWLEDGMENTS}

Authors express their gratitude to the T.L. Laura Edith Martínez Contreras and T.L. María de Lourdes Maya Salazar for their invaluable support. To M.F. Fermin Bravo Quirino for his support to sunflower cultivation. This work was carried out within the project "Evaluation of the sustainability of systems of milk production in small scale" funded by CONACYT with key 129449 CB-2009 and thanks to funding from the Agencia Española de Cooperación Internacional para el Desarrollo de España through the key project AECID 11-cap1-1526. Thanks also to the Secretaría Nacional de Educación Superior, Ciencia, Tecnología e Innovación (SENESCYT) of the Government of Ecuador for graduate studies grant for Ramón Gonzalo Aragadvay Yungán.

\section{End of english version}

5. Dulphy JP, Demarquilly C. Correction de la teneur en matière sèche des ensilages. Prévision de la Valeur Nutritive des Aliments des Ruminants, INRA Publications, Versailles. 1981.

6. De Boever JL, Cottyn BG, De Brabander DL, Vanacker JM, Boucqué ChV. Prediction of the feeding value of grass silages by chemical parameters, in vitro digestibility and near- 


\section{ENSILAJE DE GIRASOL COMBINADO CON ENSILAJE DE MAÍZ}

infrared reflectance spectroscopy. Anim Feed Sci Technol 1996; 60: 103-115.

7. AOAC. Official methods of analysis. 15th ed. Arlington, VA, USA: Association of Official Analytical Chemists. 1990.

8. AFRC. Animal and Food Research Council. Energy and protein requirements of ruminants, $C A B$ International, Wallingford, UK. 1993.

9. Ankom Technology. Procedures for NDF, ADF, and in vitro digestibility ANKOM Technology Method. http:// www.ankom.com/ 2005. Accessed March 25, 2006.

10. Theodorou MK, Williams BA, Dhanoa MS, McAllan AB, France $\mathrm{J}$. A simple gas production method using a pressure transducer to determine the fermentation kinetics of ruminants feeds. Anim Feed Sci Technol 1994;48:185-197.

11. Pell AN, Schofield P. Computerized monitoring of gas production to measure forage digestion in vitro. J Dairy Sci 1993; 76:1063-1073.

12. Krishnamoorthy $U$, Soller $H$, Steingass $H$, Menke KH. A comparative study on rumen fermentation of energy supplements in vitro. J Anim Physiol Anim Nutr 1991;65:2835.

13. Grafit. Version 3. Data analysis and graphics program. Erithacus Software LId. 1992.

14. Minitab, Statistical Software (Version 13.32). Minitab Inc., Philadelphia, PA, USA. 2000.

15. Mafakher E, Meskarbashee M, Hassibi P, Mashayekhi MR. Study of chemical composition and quality characteristics of corn, sunflower and corn-sunflower mixture silages. Asian J Anim Vet Adv 2010;5(2):175-179.
16. Pippard CJ, Porter MG, Steen RWJ, Gordon FJ, Mayne CS, Poots RE, et al. A method for obtaining and storing uniform silage for feeding experiments. Anim Feed Sci Technol 1996; 57:87-95.

17. Tomich TR, Gonçalves LC, Tomich RGP, Rodrigues JA, Borges I. Características químicas e digestibilidade in vitro de silagens de girassol. Rev Brasileira Zoot 2004;33:16721682.

18. Bergamaschine AF, Guatura A, Isepon OJ, Alves JB. Digestibilidade e degradação in situ da silagem de girassol confeccionada com diferentes teores de matéria seca e aditivo microbiano [abstract]. Reunião Anual Sociedade Brasileira De Zootecnia. Porto Alegre 1999:36.

19. Niderkorn $V$, Baumont R. Associative effects between forages on feed intake and digestion in ruminants. Animal 2009;3(7):951-960.

20. Anil L, Park J, Phipps RH. The potential of forage maize intercrops in ruminant nutrition. Anim Feed Sci Technol 2000; 86:157-164.

21. Miron J, Zuckerman E, Adin G, Solomonb R, Shoshani E, Nikbachat $M$, et al. Comparison of two forage sorghum varieties with corn and the effect of feeding their silages on eating behavior and lactation performance of dairy cows. Anim Feed Sci Technol 2007;139:23-39.

22. Van Soest PJ. Nutritional ecology of the ruminant animal. O \& B Books, Inc., Corvallis, OR, USA. 1982.

23. García-Rodrigues A, Mandaluniz N, Flores G, Oregui LM. A gas production technique as a tool to predict organic matter digestibility of grass and maize silage. Anim Feed Sci Technol 2005;123(124):267-276. 
